\title{
Kode Autentikasi Hash pada Pesan Teks Berbasis Android
}

\author{
Yusfrizal \\ Jurusan Teknik Informatika, Universitas Potensi Utama, Medan \\ J1. K.L.Yos Sudarso Km.6,5 No.3-A Medan, Telp. 061-6640525 \\ e-mail: yusfrizal@ymail.com
}

\begin{abstract}
Abstrak
Autentikasi merupakan hal yang sangat penting dalam pengiriman informasi baik berbentuk data ataupun pesan teks. Hal ini dikarenakan dibutuhkan autentikasi terhadap keaslian dan keutuhan data pada saat pertukaran informasi. Fungsi Hash merupakan salah satu fungsi yang memberikan layanan untuk verifikasi dan autentikasi karena fungsi ini menghasilkan nilai yang unik untuk setiap masukan. Fungsi Hash disebut juga fungsi satu arah karena sangat sulit untuk mengembalikan ke input awal dengan fungsi Hash. Fungsi Hash dapat digunakan untuk menjaga keutuhan (integritas) data dengan cara membangkitkan message digest dari isi arsip (misalnya dengan menggunakan algoritma MD5). Verifikasi isi arsip dapat dilakukan secara berkala dengan membandingkan message digest dari isi arsip sekarang dengan message digest dari arsip asli. Jika terjadi perbedaan, maka disimpulkan ada modifikasi terhadap isi arsip (atau terhadap message digest yang disimpan). Tetapi bagaimanapun, Hash juga mempunyai kelemahan karena MD5 telah dianggap tidak aman penggunaannya untuk digital signature. Namun, SHA-1 masih dianggap cukup aman. Untuk lebih aman lagi, SHA-256, SHA-384 atau SHA-512 dapat digunakan. Pada aplikasi yang dirancang ini memunculkan nilai Hash yang telah digenerasi dengan berbagai fungsi Hash, meliputi MD5, SHA-1, SHA-256, SHA-384 and SHA-512. Aplikasi ini juga dapat membandingkan persamaan dua pesan teks yang diregenarasi menggunakan SHA-256.
\end{abstract}

Kata kunci: Autentikasi, Integritas, Hash, MD5, SHA.

\begin{abstract}
Authentication is very important in the delivery of information such as data or text massages. Because the need of authentication in the authenticity and data integrity. The Hash function is one of the functions that provide services for verification and authentication because it generates unique values for each input. The Hash function is also called one-way function because it is very difficult to input the initial input with a Hash function. Hash function can be used to keep of data integrity by awakening digest message from archives (for example by using MD5 algorithm). This verification of the archives can be done periodically by comparing digest message from the archives with the digest message from original archives. If the difference occurs, it can be concluded that modification has been occurred to the archives or digest message. In addition, Hashes also have weaknesses because MD5 cannot be used for digital signatures. However, SHA-1 is still pretty safe. For more safety, SHA-256, SHA-384 or SHA-512 can be used. In this application will show the Hash values generated from different Hash functions, including MD5, SHA-1, SHA-256, SHA-384 and SHA-512. The application can also compare the equality of two messages by using Hash values generated by SHA-256.
\end{abstract}

Keywords: Authentication, Integrity, Hash, MD5, SHA.

\section{Pendahuluan}

Masalah keamanan merupakan salah satu aspek penting dalam proses pengiriman informasi. Informasi yang dikirimkan harus dapat dijaga kerahasiaan dan keutuhannya agar tidak dapat disalahgunakan oleh pihak-pihak yang tidak berwenang yang menginginkan informasi tersebut.

Telepon seluler merupakan alat komunikasi yang sudah dipakai oleh sebagian besar orang di dunia. Telepon seluler menyediakan media komunikasi yang beragam dan salah satu di antaranya adalah media pesan teks atau sering disebut dengan SMS (Short Message Service). Pesan teks (SMS) merupakan suatu layanan yang memungkinkan pengguna telepon seluler untuk mengirimkan pesan singkat kepada 
pengguna telepon seluler lainnya dengan cepat dan dengan biaya yang kecil. SMS bekerja pada sistem nirkabel. Layanan pengiriman pesan singkat ini sangatlah standar dan tidak jarang para pengguna telepon seluler menggunakan layanan SMS ini untuk mengirimkan suatu pesan yang penting dan rahasia, namun para pengguna layanan SMS tersebut sering kali tidak mengetahui bahwa jalur komunikasi SMS memiliki banyak sekali celah yang memungkinkan untuk terjadinya serangan pada pesan teks yang dikirim.

Perkembangan ilmu pengetahuan dan teknologi khususnya teknologi informasi dan komunikasi membawa perubahan besar pada gaya hidup manusia. Akan tetapi kemudahan penggunaan teknologi tersebut kurang diiringi dengan kesadaran pengamanan yang memadai. Hal ini mengakibatkan ancaman terhadap keamanan data dan informasi sangat besar. Salah satu alat yang dapat digunakan untuk mengamankan data dan informasi adalah kriptografi. Menezes et al. menyatakan kriptografi adalah studi tentang teknik-teknik matematika yang berhubungan dengan aspek-aspek pengamanan informasi seperti kerahasiaan (confidentiality), keutuhan data (data integrity), autentikasi entitas (entity authentication), dan autentikasi asal data (data origin authentication). Layanan keutuhan data salah satunya dapat diperoleh dengan menggunakan fungsi Hash kriptografis (cryptographic Hash function). Mekanisme yang lain adalah dengan menggunakan skema tanda tangan digital (digital signature scheme). Layanan keutuhan data dapat mendeteksi manipulasi yang dilakukan terhadap suatu data oleh pihak yang tidak berhak. Manipulasi data mencakup penyisipan (insertion), penghapusan (deletion) dan substitusi (substitution) [1].

Saat ini, fungsi Hash sangat banyak digunakan untuk mengamankan data. Dengan memanfaatkan fungsi Hash ini, maka dapat dikembangkan suatu aplikasi keamanan pesan teks (SMS) yang memungkinkan pengguna untuk mengirimkan pesan singkat dengan aman. Aplikasi ini akan dibangun berbasis mobile pada platform Android.

\section{Metode Penelitian}

\subsection{Short Message Service (SMS)}

SMS adalah teknologi yang memungkinkan pengiriman dan penerimaan pesan antar telepon seluler. Pesan yang dikirim berupa teks yang terdiri dari kata-kata atau nomor atau kombinasi alphanumeric. SMS pertama kali muncul di Eropa pada tahun 1992. Setelah itu diadopsi ke teknologi nirkabel seperti CDMA dan TDMA. Salah satu kelebihan dari sarana pertukaran informasi menggunakan SMS yaitu merupakan sebuah fitur dasar pada sebuah handphone sehingga bisa digunakan semua handphone tanpa memerlukan instalasi [2].

Di bawah ini menunjukkan arsitektur dari SMS yang di integrasikan dengan jaringan GSM. Ada tiga elemen tambahan yaitu Short Message Entity (SME), Short Message Service Center (SMSC) dan email gateway [3].

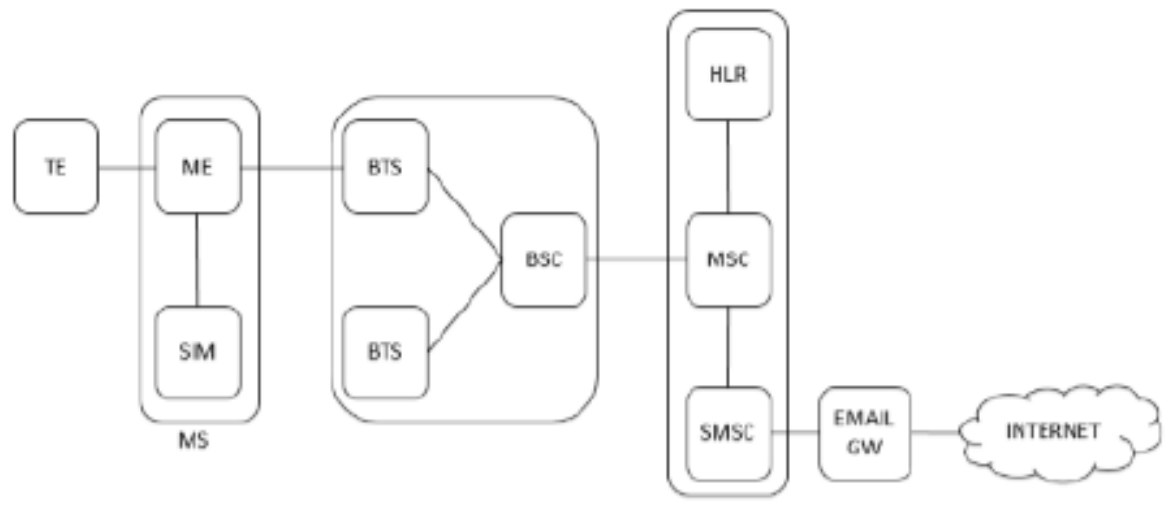

Gambar 1. Arsitektur SMS.

Keterangan gambar:

a. Terminal Equipment (TE) merupakan perangkat yang di gunakan seperti HP yang terhubung dengan ME.

b. Mobile Equipment (ME) terdiri dari pemancar radio, display dan DSP.

c. Subscribe Identity Module (SIM) berfungsi untuk mengidentifikasi user pada jaringan.

d. Base Transceiver Station (BTS) terdiri dari pemancar radio untuk berkomunikasi dengan MS. 
e. Base Station Controler (BSC) berfungsi untuk mengatur radio resources untuk satu atau lebih BTS.

f. Home Location Register (HLR) merupakan database yang memiliki data pelanggan tetap.

g. Mobile Switching Center (MSC) melaksanakan fungsi seperti registrasi, authentication, update lokasi.

h. SMS Center (SMSC) mengatur proses pengiriman dan penerimaan pesan dari dan atau menuju SME sesuai dengan proses store and forward.

i. Email gateway, sebuah gateway yang menghubungkan antara email dan SMS pada intenet.

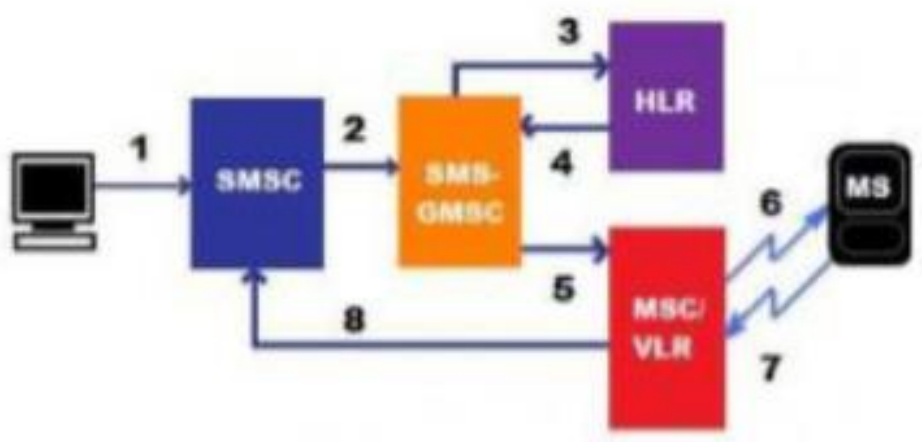

Gambar 2. Diagram alir SMS mobile.

Adapun tahapan pengiriman SMS mobile dapat dilihat pada diagram alir berikut:

a. ME mengirim pesan ke SMSC.

b. SMSC mengirimkan pesan ke SMS-GMSC.

c. SMS-GMSC menghubungi HLR untuk informasi routing.

d. HLR membalas informasi routing ke SMS-GMSC.

e. SMS-GMSC meneruskan pesan ke MSC/VLR.

f. MS di-paging dan koneksi terbentuk antara MS dan network, sebagaimana dalam setup panggilan normal. (Dengan demikian posisi MS diketahui dan apakah MS boleh berada dalam network/proses autentikasi).

g. Jika autentikasi berhasil, MSC/VLR mengirim pesan tersebut ke MS.

h. Jika pengiriman berhasil, delivery report dikirim dari MSC/VLR ke SMSC. Namun jika tidak, MSC/VLR akan menginformasikan ke HLR dan failure report dikirim ke SMS-C. Pada kasus pengiriman yang gagal HLR dan VLR akan mendapat informasi "Message Waiting" yang menunjukkan ada pesan di SMSC yang menunggu untuk dikirimkan ke MS. Informasi di HLR terdiri dari list SMSC pengiriman pesan, sedangkan di VLR terdapat "flag" yang menunjukkan apakah list pesan dalam keadaan kosong atau tidak. Jika MS available dan siap menerima pesan maka, HLR akan memberi tahu SMSC [3].

\subsection{Android}

Sistem Operasi Android merupakan sebuah sistem operasi yang berbasis Linux untuk telepon seluler seperti telepon pintar dan komputer tablet. Sistem operasi ini bersifat open source (terbuka) sehingga para programmer dapat membuat aplikasi secara mudah untuk digunakan oleh bermacam perangkat bergerak (misalnya telepon seluler). Karena sistem operasi Android ini merupakan aplikasi open source maka dapat dilakukan modifikasi dan penyebaran secara bebas [4].

Android SDK adalah tools API (Application Programming Interface) yang diperlukan untuk mulai mengembangkan aplikasi pada platform Android menggunakan bahasa pemrograman Java. Pemrograman Android membutuhkan bagian tambahan, yaitu plug-in untuk berjalan dalam Eclipse yang berupa ADT (Android Development Toolkit) dan Android SDK (Software Development Kit) [5].

Pengembang memiliki beberapa pilihan ketika membuat aplikasi yang berbasis Android. Kebanyakan pengembang menggunakan Eclipse yang tersedia secara bebas untuk merancang dan mengembangkan aplikasi Android. Eclipse adalah IDE yang paling popular untuk pengembangan Android, karena memiliki Android plug-in yang tersedia untuk memfasilitasi pengembangan Android. Selain itu Eclipse juga mendapat dukungan langsung dari Google untuk menjadi IDE pengembangan aplikasi Android, ini terbukti dengan adanya penambahan plugins untuk Eclipse untuk membuat project 
Android dimana source software langsung dari situs resminya Google. Tetapi hal di atas tidak menutup kemungkinan untuk menggunakan IDE yang lain seperti Netbeans untuk melakukan pengembangan Android [6].

\subsection{Hash Message Authentication Code}

Hash Message Authentication Code pada pesan teks adalah suatu metode authentication untuk pesan (HMAC) atau naskah menggunakan secure Hashing dan kunci rahasia. Jika $k$ adalah kunci rahasia dan $m$ adalah pesan atau naskah, maka rumus yang digunakan adalah [7]:

$$
\left.H M A C(k, m)=H\left(\left(k \oplus p_{0}\right) \pm H\left(k \oplus p_{i}\right) \pm m\right)\right)
$$

Dimana $H$ adalah fungsi secure Hashing (contohnya MD5 atau SHA-1), \pm adalah operasi penyambungan (concatenation), $p_{0}$ dan $p_{i}$ masing-masing merupakan padding sebesar blok yang digunakan $H$. Padding $p_{0}$ berisi byte 0x5c (hexadecimal) yang diulang untuk memenuhi blok, dan padding $p_{i}$ berisi byte 0x36 (hexadecimal) yang diulang untuk memenuhi blok. Jika kunci $k$ lebih kecil dari blok, maka $k$ di-padding dengan $O$ sampai memenuhi blok. Jika $k$ lebih besar dari blok, maka $k$ dipotong belakangnya hingga besarnya sama dengan blok. Metode HMAC digunakan karena metode yang menggunakan rumus berikut [7]:

$$
\operatorname{MAC}(k, m)=H(k \pm m)
$$

Mempunyai kelemahan yaitu kelemahan terhadap length extension attack. Tergantung dari fungsi $H$, seseorang dapat menambahkan sesuatu (misalnya $m_{a}$ ) ke $m$ :

$$
m_{0}=m \pm m a
$$

Dan tanpa mengetahui $k$ dapat membuat:

$$
\operatorname{MAC}\left(k ; m_{0}\right)
$$

Metode HMAC menggunakan MD5 dinamakan HMAC-MD5. Demikian juga, metode HMAC menggunakan SHA-1 dinamakan HMAC-SHA-1. Dua contoh algoritma secure Hashing adalah MD5 dan SHA-1. MD5 telah dianggap tidak aman penggunaannya untuk digital signature. SHA-1, meskipun memiliki kelemahan, masih dianggap cukup aman. Untuk lebih aman lagi, SHA-256, SHA-384 atau SHA-512 dapat digunakan.

\section{Hasil dan Pembahasan}

Fungsi Hash yang akan diimplementasikan pada aplikasi ini yaitu MD5, SHA-1, SHA-256, SHA-384 dan SHA-512. Aplikasi ini juga membandingkan persamaan antara dua pesan dengan menggunakan fungsi Hash yang digenerasi menggunakan SHA-256.

\subsection{MD5}

Secara garis besar, algoritma fungsi Hash MD5 terdiri dari langkah-langkah sebagai berikut [6]:

1. Pre-processing pesan dengan penambahan bit pengganjal (padding bits) dan nilai panjang pesan.

2. Inisialisasi nilai digest (disebut penyangga/buffer)

3. Pemrosesan tiap blok pesan 512 bit untuk mentransformasikan nilai digest.

Algoritma secure Hashing MD5 dirancang oleh Ron Rivest dan penggunaannya sangat populer di kalangan komunitas open source sebagai checksum untuk file yang dapat di-download. MD5 juga kerap digunakan untuk menyimpan password dan juga digunakan dalam digital signature dan certificate. Besarnya blok untuk MD5 adalah 512 bit sedangkan digest size adalah 128 bit. Karena word size ditentukan sebesar 32 bit, satu blok terdiri dari 16 word sedangkan digest terdiri dari 4 word. Indeks untuk bit dimulai dari 0. Preprocessing dimulai dengan padding sebagai berikut:

1. Bit dengan nilai 1 ditambahkan setelah akhir naskah. 
2. Deretan bit dengan nilai 0 ditambahkan setelah itu sehingga besar dari naskah mencapai nilai 448 ( $\bmod 512$ ) (sedikitnya 0 dan sebanyaknya 511 bit dengan nilai 0 ditambahkan sehingga tersisa 64 bit untuk diisi agar besar naskah menjadi kelipatan 512).

3. 64 bit yang tersisa diisi dengan besar naskah asli dalam bit. Jika besar naskah asli lebih dari 264 bit maka hanya 64 lower order bit yang dimasukkan. Lower order word untuk besar naskah asli dimasukkan sebelum high order word.

Setelah padding, naskah terdiri dari $n$ word $M[0 \ldots n-1]$ dimana $n$ adalah kelipatan 16. Langkah berikutnya dalam preprocessing adalah menyiapkan $M D$ buffer sebesar 4 word:

$(\mathrm{A}, \mathrm{B}, \mathrm{C}, \mathrm{D})$.

Dimana $A$ merupakan lower order word. Buffer diberi nilai awal sebagai berikut (nilai dalam hexadecimal dimulai dengan lower order byte).

$\begin{array}{llllll}\mathrm{A} & : & 01 & 23 & 45 & 67 \\ \mathrm{~B} & : & 89 & a b & c d & \text { ef } \\ \mathrm{C} & : & f e & d c & b a & 98 \\ \mathrm{D} & : & 76 & 54 & 32 & 10\end{array}$

Proses Hashing dilakukan per blok, dengan setiap blok melalui 4 putaran. Proses Hashing menggunakan 4 fungsi $F, G, H$, dan $I$ yang masing-masing mempunyai input 3 word dan output 1 word:

$\begin{array}{lll}\mathrm{F}(\mathrm{X}, \mathrm{Y}, \mathrm{Z}) & = & \left(\mathrm{X}^{\wedge} \mathrm{Y}\right) \vee\left(\neg \mathrm{X}^{\wedge} \mathrm{Z}\right) \\ \mathrm{G}(\mathrm{X}, \mathrm{Y}, \mathrm{Z}) & = & \left(\mathrm{X}^{\wedge} \mathrm{Z}\right) \vee\left(\mathrm{Y}^{\wedge} \neg \mathrm{Z}\right) \\ \mathrm{H}(\mathrm{X}, \mathrm{Y}, \mathrm{Z}) & = & \mathrm{X} \oplus \mathrm{Y} \oplus \mathrm{Z} \\ \mathrm{I}(\mathrm{X}, \mathrm{Y}, \mathrm{Z}) & = & \mathrm{Y} \oplus(\mathrm{X} \vee \neg \mathrm{Z})\end{array}$

Dimana ${ }^{\wedge}$ adalah bitwise and, $\vee$ adalah bitwise or, $\oplus$ adalah bitwise exclusive or, dan $\neg$ adalah bitwise not (one's complement). Selain keempat fungsi di atas, proses Hashing juga menggunakan tabel dengan 64 word, T[1] sampai dengan T[64].

Secara garis besar, algoritma untuk Hashing untuk satu blok adalah sebagai berikut (menggunakan array 16 word X[0] sampai dengan X[15] yang dapat menyimpan satu blok:

1. Copy satu blok (word $\mathrm{M}[16 i]$ sampai dengan $\mathrm{M}[16 i+15]$ ) ke $\mathrm{X}[0]$ sampai dengan $\mathrm{X}[15]$.

2. Simpan A,B,C,D dalam $\mathrm{A}^{\prime}, \mathrm{B}^{\prime}, \mathrm{C}^{\prime}, \mathrm{D}^{\prime}$.

3. Lakukan putaran 1 pada A,B,C,D.

4. Lakukan putaran 2 pada A,B,C,D.

5. Lakukan putaran 3 pada A,B,C,D.

6. Lakukan putaran 4 pada A,B,C,D.

7. Tambahkan nilai simpanan pada A,B,C,D:

$$
\begin{aligned}
& \mathrm{A} \rightarrow\left(\mathrm{A}+\mathrm{A}^{\prime}\right) \bmod 2^{32} \\
& \mathrm{~B} \rightarrow\left(\mathrm{B}+\mathrm{B}^{\prime}\right) \bmod 2^{32} \\
& \mathrm{C} \rightarrow\left(\mathrm{C}+\mathrm{C}^{\prime}\right) \bmod 2^{32} \\
& \mathrm{D} \rightarrow\left(\mathrm{D}+\mathrm{D}^{\prime}\right) \bmod 2^{32}
\end{aligned}
$$

Algoritma di atas diulang hingga semua blok dalam $M$ terproses (dimulai dengan $i=0$ sampai dengan $i=n / 16$ - 1). Setelah semua blok diproses, maka hasil akhir A,B,C,D menjadi MD5 digest dari naskah asli. Urutan byte untuk digest dimulai dengan lower order byte dari A dan diakhiri oleh higher order byte dari $D$.

\subsection{SHA}

Algoritma secure Hashing SHA dirancang oleh National Security Agency (NSA) dan dijadikan standard FIPS. Ada 4 varian SHA dalam standar FIPS-180-2 dengan parameter yang berbeda. Keamanan algoritma didasarkan pada fakta bahwa birthday attack pada digest sebesar $n$ bit menghasilkan collision dengan faktor kerja sekitar $2^{\text {n/2 }}$. Kita hanya akan membahas SHA-1 di sini karena SHA-256, SHA-384 dan SHA-512 algoritmanya mirip dengan SHA-1. 
Tabel 1. Empat varian SHA.

\begin{tabular}{ccccc}
\hline Algoritma & $\begin{array}{c}\text { Naskah } \\
\text { (bit) }\end{array}$ & $\begin{array}{c}\text { Blok } \\
\text { (bit) }\end{array}$ & $\begin{array}{c}\text { Word } \\
\text { (bit) }\end{array}$ & $\begin{array}{c}\text { Keamanan } \\
\text { (bit) }\end{array}$ \\
\hline SHA-1 & $<2^{64}$ & 512 & 160 & 80 \\
\hline SHA-256 & $<2^{64}$ & 512 & 256 & 128 \\
\hline SHA-384 & $<2^{128}$ & 1024 & 384 & 192 \\
\hline SHA-512 & $<2^{128}$ & 1024 & 512 & 256 \\
\hline
\end{tabular}

SHA-1 menggunakan fungsi $f_{t}$, dimana $0 \leq t<79$, dengan input 3 word masing-masing sebesar 32 bit dan menghasilkan output 1 word:

$$
f t=\left\{\begin{array}{lc}
\operatorname{Ch}(x, y, z)=(x \wedge y) \oplus(\neg x \wedge z) & 0 \leq t \leq 19 \\
\operatorname{Parity}(x, y, z)=x \oplus y \oplus z & 20 \leq t \leq 39 \\
\operatorname{Maj}(x, y, z)=(x \wedge y) \oplus(x \wedge z) \oplus(y \wedge z) & 40 \leq t \leq 59 \\
\operatorname{Parity}(x, y, z)=x \oplus y \oplus z & 60 \leq t \leq 79
\end{array}\right.
$$

SHA-1 menggunakan konstan $k_{t}$ sebagai berikut (dengan nilai dalam hexadecimal):

$$
k t=\left\{\begin{array}{lc}
5 a 827999 & 0 \leq t \leq 19 \\
6 e d 9 e b a 1 & 20 \leq t \leq 39 \\
8 f 1 b b c d c & 40 \leq t \leq 59 \\
c a 62 c 1 d 6 & 60 \leq t \leq 79
\end{array}\right.
$$

Selain enam fungsi logika yang digunakan, SHA-256 juga menggunakan nilai konstanta $\mathrm{K}$ [0..63]. Berikut nilai konstanta K[0..63] [8]:

\begin{tabular}{|c|c|c|c|}
\hline $428 \mathrm{a} 2 \mathrm{f} 98$ & 71374491 & b5c0fbcf & e9b5dba5 \\
\hline $3956 c 25 b$ & $59 \mathrm{f} 111 \mathrm{f} 1$ & $923 \mathrm{f} 82 \mathrm{a} 4$ & ab1c5ed5 \\
\hline d807aa98 & $12835 b 01$ & 243185be & $550 \mathrm{c} 7 \mathrm{dc} 3$ \\
\hline 72 be $5 d 74$ & $80 \mathrm{deb} 1 \mathrm{fe}$ & $9 \mathrm{bdc} 06 \mathrm{a} 7$ & c19bf174 \\
\hline $\mathrm{e} 49 \mathrm{~b} 69 \mathrm{c} 1$ & efbe & $0 \mathrm{fc} 1 \mathrm{C}$ & alcc \\
\hline $2 \mathrm{de} 92 \mathrm{c} 6 \mathrm{f}$ & $4 a 74$ & $5 \mathrm{cb} 0$ & $8 \mathrm{da}$ \\
\hline $983 \mathrm{e} 5152$ & a831c66d & b00327c8 & bf597fc7 \\
\hline $\mathrm{c} 6 \mathrm{e} 00$ & & $06 \mathrm{ca}$ & 967 \\
\hline $27 \mathrm{~b} 70$ & $2 \mathrm{e} 1 \mathrm{l}$ & & d13 \\
\hline $650 \mathrm{a} 7$ & $766 a 0 a b b$ & $81 c$ & 9272 \\
\hline a2bfe8a1 & a81a664b & $\mathrm{c} 24 \mathrm{~b} 8 \mathrm{~b} 70$ & c76c51a3 \\
\hline d192e819 & d6990624 & $\mathrm{f} 40 \mathrm{e}$ & $106 \mathrm{aa} 070$ \\
\hline $19 \mathrm{a} 4 \mathrm{c} 116$ & $1 \mathrm{e} 376 \mathrm{c} 08$ & $2748774 \mathrm{c}$ & $34 b 0 b c b 5$ \\
\hline $391 \mathrm{c} 0 \mathrm{cb} 3$ & 4ed8aa4a & $5 b 9 c c a 4 f$ & $682 \mathrm{e} 6 \mathrm{ff} 3$ \\
\hline 748f82ee & $78 a 5636 f$ & $84 c 87814$ & $8 \mathrm{cc} 70208$ \\
\hline 90befffa & $\mathrm{a} 4506 \mathrm{ceb}$ & bef9a3f7 & c67178f2 \\
\hline
\end{tabular}

Tabel 2. Nilai K[0..63]

Seperti halnya dengan MD5, SHA-1 terdiri dari dua tahap yaitu preprocessing dan Hashing. Preprocessing dimulai dengan padding yang prosesnya persis sama dengan MD5, yaitu setelah akhir naskah, 1 bit dengan nilai 1 ditambahkan, disusul oleh bit dengan nilai 0 sebanyak 0 sampai dengan 511 tergantung panjang naskah, dan diakhiri dengan 64 bit yang merepresentasikan besar naskah asli. Setelah padding, naskah terdiri dari $n$ word $\mathrm{M}[0 \ldots \mathrm{n}-1]$ dimana $n$ adalah kelipatan 16. Langkah berikutnya dalam preprocessing adalah menyiapkan SHA-1 buffer sebesar 5 word:

$$
\left(H_{0}^{(0)}, H_{I}^{(0)}, H_{2}^{(0)}, H_{3}^{(0)}, H_{4}^{(0)}\right)
$$

Buffer diberi nilai awal sebagai berikut (nilai dalam hexadecimal):

$$
\mathrm{H}_{0}{ }^{(0)} \rightarrow 67452301
$$




$$
\begin{aligned}
\mathrm{H}_{1}{ }^{(0)} & \rightarrow \text { efcdab89 } \\
\mathrm{H}_{2}{ }^{(0)} & \rightarrow 98 \text { badcfe } \\
\mathrm{H}_{3}{ }^{\left({ }^{0}\right)} & \rightarrow 10325476 \\
\mathrm{H}_{4}{ }^{(0)} & \rightarrow c 3 d 2 e 1 f 0
\end{aligned}
$$

Setelah buffer diberi nilai awal, tahap kedua yaitu Hashing dilakukan terhadap setiap blok $\left(\mathbf{M}^{(1)}, \mathbf{M}^{(2)} \ldots, \mathrm{M}^{(\mathrm{n})}\right)$ sebagai berikut $(\mathrm{i}=1,2, \ldots, \mathrm{n})$ :

1. Siapkan message schedule $\{\mathrm{Wt}\}$ :

$$
W t \leftarrow\left\{\begin{array}{lr}
M t^{(i)} & 0 \leq t \leq 15 \\
(W t-3 \oplus W t-8 \oplus W t-14 \oplus W t-16<<<1 & 16 \leq t \leq 79
\end{array}\right.
$$

2. Berikan nilai awal untuk variabel $a, b, c, d$, dan $e$ :

$$
\begin{aligned}
& \mathrm{a} \rightarrow \mathrm{H}_{1}{ }^{(\mathrm{i}-1)} \\
& \mathrm{b} \rightarrow \mathrm{H}_{2}{ }^{(\mathrm{i}-1)} \\
& \mathrm{c} \rightarrow \mathrm{H}_{3}(\mathrm{i}-1) \\
& \mathrm{d} \rightarrow \mathrm{H}_{4}{ }^{(\mathrm{i}-1)} \\
& \mathrm{e} \rightarrow \mathrm{H}_{5}(\mathrm{i}-1)
\end{aligned}
$$

3. Untuk $\mathrm{t}=0,1,2, \ldots, 79$ :

$$
\begin{aligned}
& \mathrm{T} \rightarrow(\mathrm{a}<<<5)+\mathrm{f}_{\mathrm{t}}(\mathrm{b}, \mathrm{c}, \mathrm{d})+\mathrm{e}+\mathrm{Kt}+\mathrm{Wt}\left(\bmod 2^{32}\right) \\
& \mathrm{e} \rightarrow \mathrm{d} \\
& \mathrm{d} \rightarrow \mathrm{c} \\
& \mathrm{c} \rightarrow \mathrm{b}<<<30 \\
& \mathrm{~b} \rightarrow \mathrm{a} \\
& \mathrm{a} \rightarrow \mathrm{T}
\end{aligned}
$$

4. Lakukan kalkulasi Hash value tahap $i$ :

$$
\begin{aligned}
& \mathrm{H}_{0}{ }^{\mathrm{i}} \rightarrow \mathrm{a}+\mathrm{H}_{0}{ }^{\mathrm{i}} \\
& \mathrm{H}_{1}{ }^{\mathrm{i}} \rightarrow \mathrm{b}+\mathrm{H}_{1}{ }^{\mathrm{i}} \\
& \mathrm{H}_{2}{ }^{\mathrm{i}} \rightarrow \mathrm{c}+\mathrm{H}_{2}{ }^{\mathrm{i}} \\
& \mathrm{H}_{3}{ }^{\mathrm{i}} \rightarrow \mathrm{d}+\mathrm{H}_{3}{ }^{\mathrm{i}} \\
& \mathrm{H}_{4}{ }^{\mathrm{i}} \rightarrow \mathrm{e}+\mathrm{H}_{4}{ }^{\mathrm{i}}
\end{aligned}
$$

5. Setelah Hashing dilakukan pada semua blok $\left(\mathrm{M}^{(1)}, \mathrm{M}^{(2)}, \ldots, \mathrm{M}^{(\mathrm{n})}\right)$, kita dapatkan digest sebagai berikut:

$$
\left(\mathrm{H}_{0}{ }^{(\mathrm{n})} ; \mathrm{H}_{1}^{(\mathrm{n})} ; \mathrm{H}_{2}{ }^{(\mathrm{n})} ; \mathrm{H}_{3}^{(\mathrm{n})} ; \mathrm{H}_{4}^{(\mathrm{n})}\right)
$$

Beberapa ahli kriptografi telah mencoba mencari kelemahan SHA-1. Xiaoyun Wang dan koleganya berhasil memperkecil ruang pencarian untuk collision SHA-1 dari 280 operasi SHA-1 (yang merupakan "kekuatan" teoretis SHA-1 jika SHA-1 tidak memiliki kelemahan, berdasarkan birthday attack) menjadi $2^{69}$ operasi. Walaupun demikian, penggunaan SHA-1 masih dianggap cukup aman, dan jika ingin lebih aman lagi, maka SHA-256, SHA-384 atau SHA-512 dapat digunakan.

\subsection{Pengujian}

Pada aplikasi ini, pengguna dapat mengetikkan pesan teks pada kotak pesan, kemudian menekan tombol fungsi. Maka aplikasi akan memunculkan nilai Hash yang telah digenerasi dengan berbagai fungsi Hash, meliputi MD5, SHA-1, SHA-256, SHA-384 dan SHA-512. Aplikasi ini juga dapat membandingkan persamaan dua pesan teks yang diregenerasi menggunakan SHA-256.

Berikut ini adalah beberapa tampilan pada aplikasi ini. 


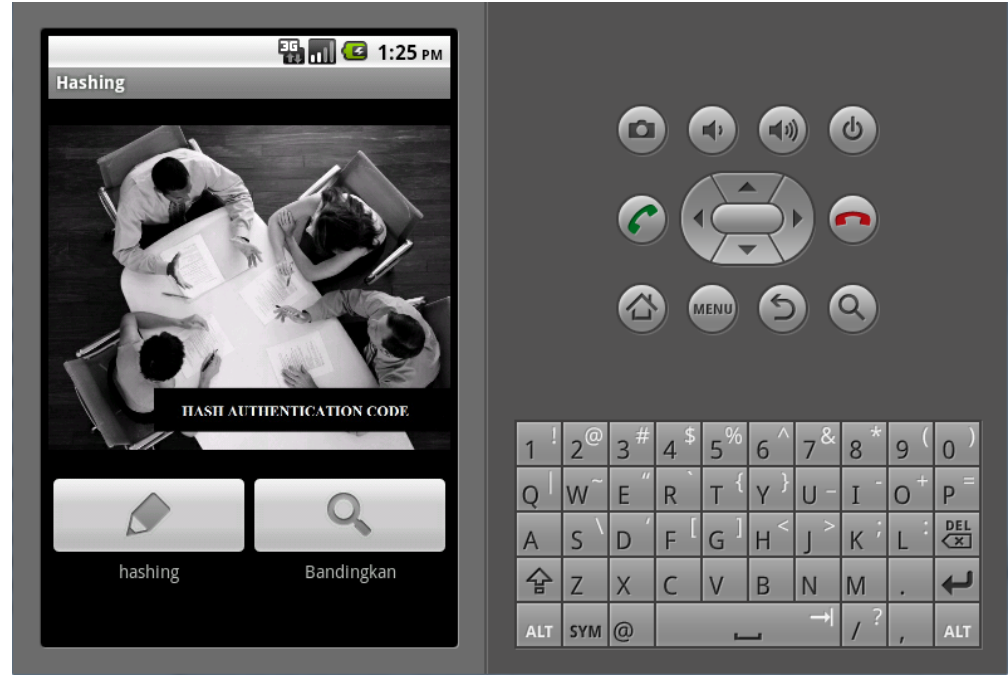

Gambar 3. Halaman utama.

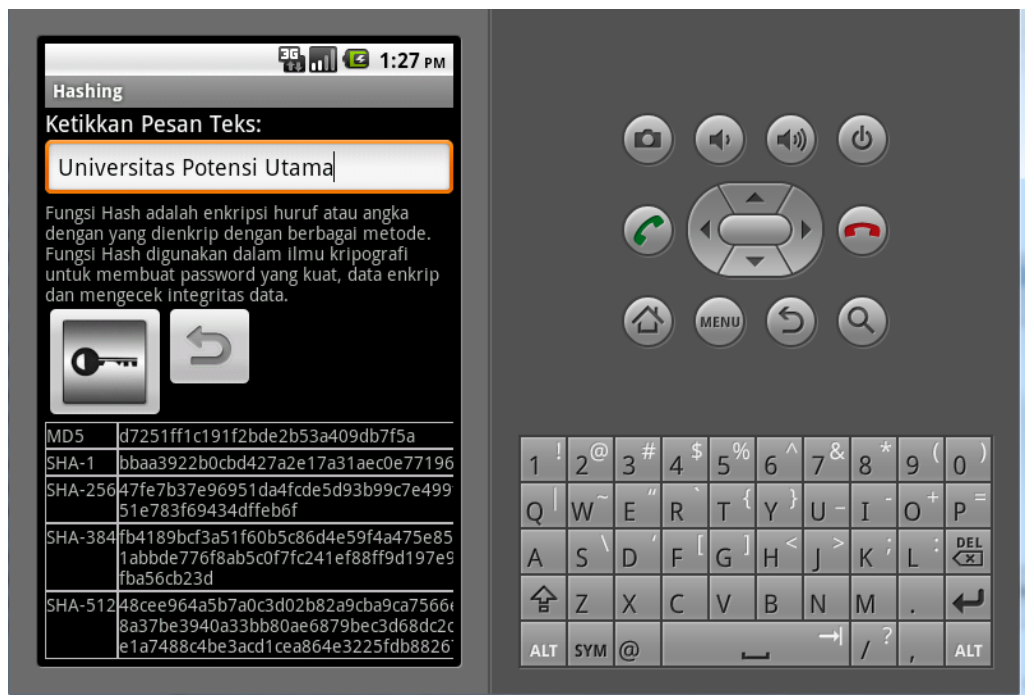

Gambar 4. Menu hashing.

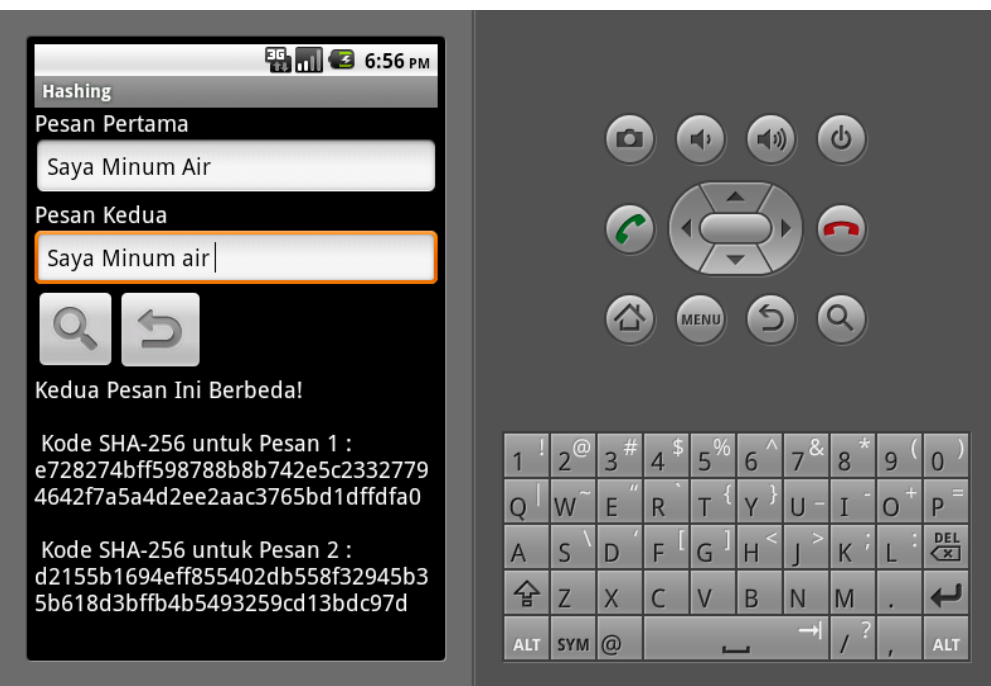

Gambar 5. Menu bandingkan. 


\section{Kesimpulan}

Dari hasil pengujian sistem yang telah dilakukan, maka dapat diambil beberapa kesimpulan diantaranya sebagai berikut:

a. Algoritma MD5 menerima masukan berupa pesan dengan ukuran sembarang dan menghasilkan message digest yang panjangnya 128 bit.

b. Fungsi Hash dapat digunakan untuk menjaga keutuhan (integritas) data. Caranya, bangkitkan message digest dari isi arsip (misalnya dengan menggunakan algoritma MD5). Message digest dapat digabung ke dalam arsip atau disimpan di dalam arsip. Verifikasi isi arsip dapat dilakukan secara berkala dengan membandingkan message digest dari isi arsip sekarang dengan message digest dari arsip asli. Jika terjadi perbedaan, maka disimpulkan ada modifikasi terhadap isi arsip (atau terhadap message digest yang disimpan).

c. MD5 telah dianggap tidak aman penggunaannya untuk digital signature. SHA-1, meskipun memiliki kelemahan, masih dianggap cukup aman. Untuk lebih aman lagi, SHA-256, SHA384 atau SHA-512 dapat digunakan.

d. Aplikasi yang dirancang dalam penelitian ini telah mampu melakukan proses verifikasi keutuhan file dengan menggunakan algoritma MD5.

e. Algoritma MD5 dapat digunakan untuk memverifikasi keutuhan dari suatu file dengan cara menghitung nilai MD5 dari file tersebut dan membandingkannya dengan nilai MD5 yang diperoleh dari si pengirim.

\section{Saran}

Beberapa hal yang perlu dikembangkan dari penelitian ini adalah :

a. Diharapkan pengembangan aplikasi yang langsung diterapkan pada pengiriman SMS.

b. Diharapkan pengembangan aplikasi yang dikombinasikan dengan algoritma-algoritma keamanan yang lain.

\section{Daftar Pustaka}

[1] Susila Windarta, 2013, Fungsi Hash Berbasis Teori Graf: Sebuah Survei, Seminar Nasional Sistem Informasi Indonesia, Skripsi, Program Studi Ilmu Komputer, Institut Teknologi Sepuluh Nopember (ITS), Surabaya.

[2] Imam Prayogo Pujiono, 2015, Implementasi Algoritma AES dan Modifikasi Vigenere untuk Pengamanan Pesan SMS Dengan Nomor Pengirim dan Penerima Sebagai Kunci Tambahan, Jurnal Algoritma, Vol. 12 No. 1, 2302-7339.

[3] Ari Dwi Ananto, 2014, Desain dan Implementasi Aplikasi SMS (Short Message Service) pada Android Menggunakan Algoritma AES, Universitas Telkom, Bandung.

[4] I Komang Setia Buana, 2015, Aplikasi Komik Untuk Toilet Training Berbasis Android, CSRID, Jurnal Sistem dan Informatika Vol. 10, No. 1, STMIK STIKOM, Bali.

[5] Dedy Hermanto, 2015, Pengontrolan Gerak Mobile Robot Menggunakan Sensor Accelerometer pada Perangkat Bergerak Android, CSRID Journal, Vol.7 No.1, AMIK Multi Data, Palembang.

[6] elib.unikom.ac.id/download.php?id=256870.

[7] Sentot Kromodimoeljo, 2009, Teori dan Aplikasi Kriptografi, SPK IT Consulting, Bandung.

[8] Steven Andrew, 2012, Pembangkit Bilangan Acak Berbasis Fungsi Hash, Makalah IF3058 Kriptografi - Sem. II, Institut Teknologi Bandung, Bandung. 